DOI: $10.17707 /$ AgricultForest.64.4.23

\author{
Bajram AVDIU, Sali ALIU, Shukri FETAHU, \\ Dukagjin ZEKA, Imer RUSINOVCI ${ }^{1}$
}

\title{
THE FLORISTIC COMPOSITION OF THE NATURAL PASTURES IN MASSIVE OF NOVOBËRDA
}

\begin{abstract}
SUMMARY
This article presents data of the research in 2017 on the floristic composition of the pastures in the Novobërda area, in the eastern part of Kosovo plain, which is characterized by a medium continental climate. This study gives an outline of the floristic composition of this massive, and also an idea on the producing capacity of the wet and dry mass of the grass in these pastures and their quality. The aim of the investigations was to examine the floristic composition and green fodder yield and quality at a number of representative sites, having in mind the distribution of natural meadows and pastures. From these studies we can survey the pasture capacity, the ratio of the edible versus non- edible vegetation, poisonous plants, and the necessity of pasture upgrading. The data of the study show the presence of variation related to the floristic composition and plant cohabitation. The average presence of grasses was higher, $48.51 \%$ compared with legumes of $25.36 \%$ and other species $26.13 \%$. The presence of legumes was relatively higher compared with investigation data presented from other authors in the region. Differences of species composition between localities were highly significant at level of $\mathrm{LSD}_{0.01}$ of probability.
\end{abstract}

Keywords: Floristic composition, yield, quality, Kosovo plain.

\section{INTRODUCTION}

Meadows (14\%) and pastures (30.2\%) occupy a significant part of the land in Kosovo and they are very important source of fodder for the livestock and for the soil protection against erosion (Rusinovci, 2016a, Rusinovci, 2016b; Avdiu, 2003). As such, they raise interest in studying their floristic composition and their values. There is interest from the point of view of knowing the vegetation biodiversity as well as how it could be intervened to improve their production potential and nutritive values. Meadows and pastures are secondary vegetation with different floristic composition and reflections of the ecological conditions, which define their physiognomy. Average meadow and pasture yield is relatively low and range from that is due to absence of essential cultural practices and sometimes from improper utilization (Rusinovci, 2015; Rexhepi, 1988; Demiri, 1981 and Mirić, 1975). There is a need for improvement of meadows and

\footnotetext{
${ }^{1}$ Bajram Avdiu, Sali Aliu, Shukri Fetahu, Dukagjin Zeka, Imer Rusinovci (corresponding author: imer.rusinovci@uni-pr.edu), Department of Crop Sciences, Faculty of Agriculture and Veterinary, University of Prishtina, Prishtinë 10000, KOSOVO.

Notes: The authors declare that they have no conflicts of interest. Authorship Form signed online.
} 
pastures through cleaning, systematization, and protection against erosion, but also to cultivate improved types of plants in order to increase their production capacities. The similar methods have been used in Western Europe and presented through the articles of many authors such as: Talamaci et al. (1990); Arigno et al. (1990); Rusinovci et al (2015). Parameters that show the quality of meadows and pastures are the chemical content of grass such as proteins, carbohydrates and fat content. The evaluation of germplasm resources has been considered of prime importance, especially on those species that have a further economic interest. (Aliu et al., 2012)

This study was focused on the need to know the capacity and value of meadows and pastures in this region. Also the yield of wet, and dry mass production will be researched that will show the quantity potential of meadows and pastures. Based on the varieties of species which were found, a strategy for genetically improvement in the field of forage crops will be developed and also this research will notify the values of floristic diversity.

\section{MATERIAL AND METHODS}

Investigations of the floristic composition were carried out over the 2017 growing season. Sampling of plant species and green matter yield determination was carried out at the optimum plant growth and developmental stage.

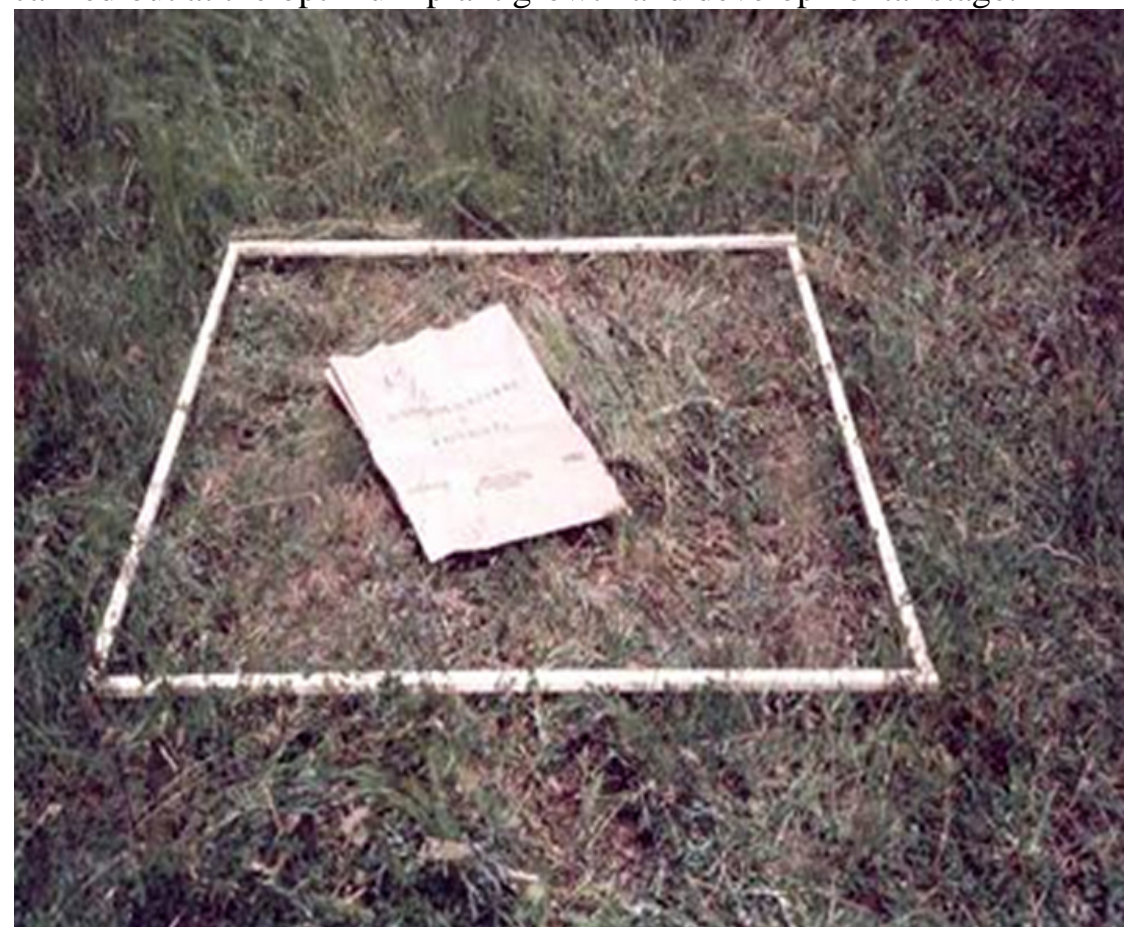

Figure 1 . The quadrate for determination the number of plant species. 
Samples were collected at 36 locations of natural pastures in region of Novobërda. From each location were taken by 3 samples which were used to calculate the average of grasses, legumes and other species.

Samples were taken depending on the altitude from 700 to $1200 \mathrm{~m}$ a.s.l., and different expositions (northern, southern, eastern, and western expositions) in order to determine their composition. Components have been determined for each sample as well as the embranchments presented by each of them. Then, the wet and dry mass of each species found was measured and calculated.

The initial sample represents plants in $1 \mathrm{~m}^{2}$. For this reason was prepared a quadrate (Figure 1.) of $1 \mathrm{~m}^{2}$. This quadrate was put in to the ground and all the plants inside the quadrate were harvested and selected by the species they belong.

Samples for determination of the floristic composition were classified in three main groups: grasses, legumes and other species. Samples were tested for the content of protein, fat and dry matter at the testing lab at Kosovo Institute of Agriculture in Peja.

Dry matter yield determination was made after sample drying at $65^{\circ} \mathrm{C}$. Standard methods were used to establish the dry matter quality: contents of crude proteins (CP), crude fiber (CF) and crude fats (CF). For statistical analyses were used SPSS 22, Minitab 18 and Excell.

\section{RESULTS AND DISCUSSION}

The floristic composition of Novobërda grasslands - Vegetation is characteristic of dry climate areas, which coincides with the studies made by other authors (Rusinovci et al, 2014a, Rusinovci et al, 2014b; Paparisto, 2000; Pardini and Talamaci, 1990).

The results showed relatively rich vegetation diversity composed in totally of 71 species include: 24 grasses, 16 leguminous, and 31 other species (table 1). Even the diversity of grasses species in our samples was almost double compare to leguminous species, the frequency of plants per square meter was quite different (table 2).

Based on our research grasses are most frequent in number per square meter, followed by similar number of other species and leguminous. The distribution of plants per square meter was different, grasses ranged from 23 to 720 , legumes from 5 to 320 and other species from 17 to 345 plants per square meter.

The distribution of grasses species was $48.51 \%$, compared to legumes 25.36\% and other species 26.13\% (Figure 2). This shows that Novobërda massive conditions favour the growth of grasses, which have to be considered for the purpose of upgrading.

Moreover, since the samples collected from different locations, results were analysed for their statistical significance, and according to the one-way ANOVA we found that between the locations for the plants frequency per square meter there was high statistical significance at level of $\mathrm{LSD}_{00.1}$ (table 2). 
Table 1. Determination of species at Novobërda massive

\begin{tabular}{|c|l|c|l|}
\hline & & & \\
No. & \multicolumn{1}{|c|}{ Scientific name } & No. & \\
& & & \\
\hline 1 & Achilea millefolium & 37 & Podosperma laciata name \\
\hline 2 & Anthoxanthum odoratum & 38 & Polygala vulgaris \\
\hline 3 & Aegilops triuncialis & 39 & Phleum pratense \\
\hline 4 & Astragalus onobrychis & 40 & Plantago lanceolata \\
\hline 5 & Ajuga laxmannii & 41 & Rumex acetosella \\
\hline 6 & Arrhenatherum elatius & 42 & Rinantus minor \\
\hline 7 & Anthyllis vulneraria & 43 & Ranunculus psilostachys \\
\hline 8 & Alopecurus myosinoides & 44 & Rinantus major \\
\hline 9 & Allium flavum & 45 & Medicago rigidula \\
\hline 10 & Asperula cynanchina & 46 & Marrubium vulgare \\
\hline 11 & Agropyron repens & 47 & Medicago falcata \\
\hline 12 & Bromus erectus & 48 & Festuca ovina \\
\hline 13 & Bromus sterilis & 49 & Festuca arundinaca \\
\hline 14 & Convolvulus arvensis & 50 & Fragaria vesca \\
\hline 15 & Capsella bursa-pastoris & 51 & Trifolium dalmaticum \\
\hline 16 & Cerinthe minor & 52 & Trifolium incarnatum \\
\hline 17 & Cruciata glabra & 53 & Trifolium pratense \\
\hline 18 & Cirsium sp & 54 & Trifolium campestre \\
\hline 19 & Chrysopogon gryllus & 55 & Trisetum flavescense \\
\hline 20 & Dactylus glomerata & 56 & Tragopogon pratense \\
\hline 21 & Dorycnium herbaceum & 57 & Thymus serpullum \\
\hline 22 & Euphorbia ciparissias & 58 & Teucrium chamedrys \\
\hline 23 & Erodium cicutarium & 59 & Salvia verticillata \\
\hline 24 & Galium verum & 60 & Seratula tinctoria \\
\hline 25 & Genista sagitalis & 61 & Silena conica \\
\hline 26 & Koeleria piramidata & 62 & Sanguisorba minor \\
\hline 27 & Lotus corniculatus & 63 & Succisa pratensis \\
\hline 28 & Haynaldia villosa & 64 & Vicia cracca \\
\hline 29 & Hypohoris radiata & 65 & Veronica sp \\
\hline 30 & Hypericum perforatum & 66 & Viola tricolor \\
\hline 31 & Hieracium pilosum & 67 & Helloborus sp. \\
\hline 32 & Onobrychis viciifolia & 68 & Trifolium arvense \\
\hline 33 & Potentilla hirta & 69 & Lathyrus aphaca \\
\hline 34 & Poa pratensis & 70 & Daucus carota \\
\hline 35 & Poa trivialis & Poa bulbosa & \\
\hline 36 & Porium sp. \\
\hline & & & \\
\hline & & & \\
\hline & & & \\
\hline & & & \\
\hline
\end{tabular}


Table 2. Frequency of grasses, legumes and other species at Novo Berda natural pastures and one-way ANOVA.

\begin{tabular}{|c|c|c|c|c|c|c|c|}
\hline Loc. & Grasses & Leguminous & Others & Loc. & Grasses & Leguminous & Others \\
\hline 1 & $172^{t}$ & $89^{\mathrm{pq}}$ & $17^{v}$ & 19 & $188^{\mathrm{s}}$ & $47^{t}$ & $120^{\mathrm{op}}$ \\
\hline 2 & $314^{\text {fgh }}$ & $90^{\text {opq }}$ & $180^{\mathrm{jk}}$ & 20 & $23^{y}$ & $107^{\operatorname{lmn}}$ & $220^{\mathrm{efg}}$ \\
\hline 3 & $299^{\mathrm{ijk}}$ & $90^{\text {opq }}$ & $22^{\mathrm{v}}$ & 21 & $69^{x}$ & $72^{\text {rs }}$ & $24^{\mathrm{uv}}$ \\
\hline 4 & $323^{\mathrm{fgh}}$ & $230^{\mathrm{cd}}$ & $345^{a}$ & 22 & $101^{\mathrm{v}}$ & $5^{v}$ & $37^{t}$ \\
\hline 5 & $290^{\mathrm{kl}}$ & $102^{\mathrm{mno}}$ & $141^{\mathrm{mn}}$ & 23 & $310^{\text {hij }}$ & $80^{\mathrm{qr}}$ & $114^{\mathrm{p}}$ \\
\hline 6 & $318^{\mathrm{fgh}}$ & $275^{\mathrm{b}}$ & $206^{\mathrm{h}}$ & 24 & $520^{c}$ & $280^{\mathrm{b}}$ & $146^{\operatorname{lm}}$ \\
\hline 7 & $210^{r}$ & $241^{\mathrm{c}}$ & $136^{\mathrm{mn}}$ & 25 & $310^{\text {hij }}$ & $124^{\mathrm{jk}}$ & $193^{\mathrm{i}}$ \\
\hline 8 & $267^{\mathrm{no}}$ & $171^{\mathrm{f}}$ & $35^{\text {tu }}$ & 26 & $273^{\mathrm{mn}}$ & $157^{g}$ & $144^{\mathrm{lm}}$ \\
\hline 9 & $298^{\mathrm{jk}}$ & $218^{\mathrm{d}}$ & $190^{\mathrm{ij}}$ & 27 & $255^{\text {op }}$ & $88^{\mathrm{pq}}$ & $175^{\mathrm{k}}$ \\
\hline 10 & $406^{\mathrm{d}}$ & $280^{b}$ & $316^{\mathrm{b}}$ & 28 & $188^{\mathrm{s}}$ & $109^{\mathrm{lm}}$ & $213^{\text {gh }}$ \\
\hline 11 & $24^{y}$ & $139^{\mathrm{hi}}$ & $130^{\text {no }}$ & 29 & $327^{\mathrm{f}}$ & $151^{\text {gh }}$ & $155^{1}$ \\
\hline 12 & $80^{w x}$ & $320^{\mathrm{a}}$ & $22^{v}$ & 30 & $126^{\mathrm{u}}$ & $117^{\mathrm{kl}}$ & $235^{\mathrm{d}}$ \\
\hline 13 & $720^{\mathrm{a}}$ & $137^{\mathrm{i}}$ & $120^{\mathrm{op}}$ & 31 & $284^{\mathrm{Im}}$ & $122^{\mathrm{jk}}$ & $274^{\mathrm{c}}$ \\
\hline 14 & $696^{\mathrm{b}}$ & $130^{\mathrm{ij}}$ & $226^{\text {def }}$ & 32 & $87^{w}$ & $95^{\text {nop }}$ & $236^{\mathrm{d}}$ \\
\hline 15 & $246^{\mathrm{pq}}$ & $240^{c}$ & $25^{\text {tuv }}$ & 33 & $219^{r}$ & $162^{\mathrm{fg}}$ & $187^{\mathrm{ijk}}$ \\
\hline 16 & $192^{\mathrm{s}}$ & $161^{\mathrm{fg}}$ & $20^{\mathrm{v}}$ & 34 & $365^{\mathrm{e}}$ & $122^{\mathrm{ijk}}$ & $231^{\mathrm{df}}$ \\
\hline 17 & $412^{\mathrm{d}}$ & $79^{\text {grs }}$ & $51^{\mathrm{s}}$ & 35 & $235^{9}$ & $184^{\mathrm{e}}$ & $214^{\mathrm{fgh}}$ \\
\hline 18 & $325^{\mathrm{fg}}$ & $26^{\mathrm{u}}$ & $101^{9}$ & 36 & $312^{\text {ghi }}$ & $67^{5}$ & $69^{r}$ \\
\hline \multicolumn{5}{|c|}{ Mean $\left(\mathrm{m}^{2}\right)$} & 271.78 & 142.06 & 146.39 \\
\hline \multicolumn{5}{|l|}{$F$} & $1936.42 * *$ & $520.97 * *$ & $764.82^{* *}$ \\
\hline \multicolumn{5}{|c|}{$\operatorname{LSD}_{0.05}$} & 9.72 & 9.24 & 8.92 \\
\hline \multicolumn{5}{|c|}{$\operatorname{LSD}_{0.01}$} & 12.78 & 12.14 & 11.73 \\
\hline
\end{tabular}

Means that don't share a latter are significantly different at level of $p<0.01$.

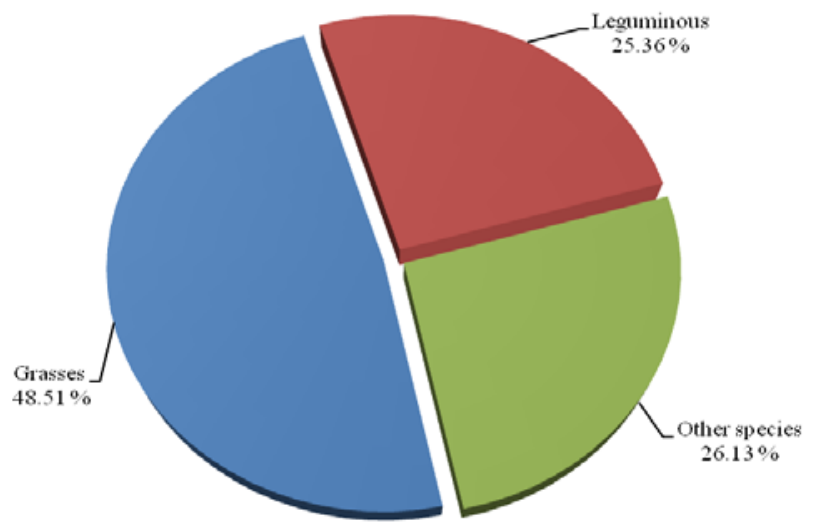

Figure 2. Distribution of plant species at natural pastures . 
It's valuable to mention that grasses species occurred with higher diversity and frequency in north-west exposure and higher altitude, whereas leguminous species had a slight dominance in lower altitude and south-east exposure. Also, other grasses species with some exceptions, had the same extension like leguminous species. These exceptions may attribute to the soil bonity.

The higher number of grasses and legumes is an indicator of high quality of pastures (Cowan, 2011). One-way ANOVA, in our research, shows significant results at level $\mathrm{LSD}_{0.01}$ of plant species richness groups in different location of Novobërda region (table 3).

Table 3. ANOVA and average weight in grams per square meter of the wet and dry mass of plant species in the Novobërda natural pastures

\begin{tabular}{|l|r|r|}
\hline \multicolumn{1}{|c|}{ Plant species } & \multicolumn{1}{c|}{ Wet mass } & \multicolumn{1}{c|}{ Dry mass } \\
\hline Grasses & $237.3^{\mathrm{a}}$ & $93.2^{\mathrm{a}}$ \\
\hline Leguminous & $143.5^{\mathrm{b}}$ & $42.2^{\mathrm{b}}$ \\
\hline Other species & $104.2^{\mathrm{c}}$ & $32.9^{\mathrm{b}}$ \\
\hline Total weight $\mathbf{g} / \mathbf{m}^{2}$ & $\mathbf{4 8 5}$ & $\mathbf{1 6 8 . 3}$ \\
\hline F & $166.10^{* *}$ & $71.50^{* *}$ \\
\hline LSD $_{005}$ & 18.36 & 13.29 \\
\hline LSD $_{001}$ & 27.82 & 20.13 \\
\hline
\end{tabular}

Means that don't share a latter are significantly different at level of $p<0.01$.

Data from the above table show that grasses has the biggest weight for wet and dry mass, which is almost double the weight of the leguminous and other families. The percentage of dry mass compare to the wet mass appears to be higher for grasses for approximately $40 \%$. It appears to be lower for the other species. The content of the dry matter, mineral matter, proteins, fats, fibbers, and nitrogen free extracts of natural pastures are presented on table 4.

Table 3. Chemical composition \% of natural pastures and one-way ANOVA.

\begin{tabular}{|l|c|c|c|c|c|c|c|}
\hline Plant species & Moisture & $\begin{array}{c}\text { Dry } \\
\text { Matter }\end{array}$ & $\begin{array}{c}\text { Mineral } \\
\text { content }\end{array}$ & $\begin{array}{c}\text { Crude } \\
\text { Proteins }\end{array}$ & $\begin{array}{c}\text { Crude } \\
\text { Fats }\end{array}$ & $\begin{array}{c}\text { Crude } \\
\text { Fibber }\end{array}$ & $\begin{array}{c}\text { Nitrogen } \\
\text { Free } \\
\text { Extracts }\end{array}$ \\
\hline Grasses & $8.59^{\mathrm{a}}$ & $91.59^{\mathrm{a}}$ & $6.00^{\mathrm{a}}$ & $10.00^{\mathrm{ab}}$ & $1.61^{\mathrm{a}}$ & $34.50^{\mathrm{a}}$ & $39.90^{\mathrm{a}}$ \\
\hline Legumes & $8.50^{\mathrm{a}}$ & $91.50^{\mathrm{a}}$ & $6.98^{\mathrm{a}}$ & $13.31^{\mathrm{a}}$ & $1.73^{\mathrm{a}}$ & $30.38^{\mathrm{a}}$ & $39.06^{\mathrm{a}}$ \\
\hline Other species & $8.69^{\mathrm{a}}$ & $91.31^{\mathrm{a}}$ & $6.28^{\mathrm{a}}$ & $11.07^{\mathrm{ab}}$ & $1.85^{\mathrm{a}}$ & $33.00^{\mathrm{a}}$ & $39.12^{\mathrm{a}}$ \\
\hline Mean & $\mathbf{8 . 5 9}$ & $\mathbf{9 1 . 4 1}$ & $\mathbf{6 . 4 2}$ & $\mathbf{1 1 . 4 6}$ & $\mathbf{1 . 7 3}$ & $\mathbf{3 2 . 6 3}$ & $\mathbf{3 9 . 3 6}$ \\
\hline $\mathrm{F}$ & 0.09 & 0.09 & 2.41 & $13.65^{* *}$ & 1.43 & 4.40 & 0.11 \\
\hline $\mathrm{LSD}_{005}$ & 1.11 & 1.11 & 1.12 & 1.58 & 0.36 & 3.44 & 4.83 \\
\hline LSD $_{001}$ & 1.68 & 1.68 & 1.70 & 2.40 & 0.54 & 5.21 & 7.32 \\
\hline
\end{tabular}

Means that don't share a latter are significantly different at level of $p<0.01$. 
Data show that there is a significant difference at level of $\mathrm{LSD}_{001}$ between legumes compare to the grasses and other species on crude protein content. The pastures with large legumes specie or their frequency per unit were characterized with high content of crude proteins.

\section{CONCLUSIONS}

The following conclusions derive from the study of the floristic and grazing composition of Novobërda pasture massive: Pastures of Novobërda massive consist of a rich diversity of vegetation, which is shows cohabitation of 71 plant species. The distribution of plants species and their frequency in different locations of the study was different. This seems to be related to the altitude, exposition and the composition of the soil characters of this massive. The average presence of grasses was higher, $48.51 \%$ compared with legumes of $25.36 \%$ and other species $26.13 \%$. The wet and dry weight of the grass per unit of area varies significantly from one sampling location to the other. This is related to the environmental factors such as exposition, solid composition, altitude, which affect the composition of the grass.

\section{REFERENCES}

Arigno R., A.Porra, M.Vargiy. 1990: Green forage recourse complement to rangeland utilization in Mediterranean areas",

Avdiu B. 2003: The current state of pastures and meadows in the region of Kamenica and Novo Brdo and possibilities for their upgrading, Tirana, Albania, Pg. 2-6, 35-40.

Cowan T. 2011: Use of ensiled forages in large scale animal production systems. Australian Tropical Dairy institute

Demiri, M., 1981: The Excursionist Flora in Albania, Tirana 50-650.

Miric. M. 1975 “The basis of Kosovo fodder”. Prishtina, Kosovo.

Paparisto, K. 2000 Flora in Albania, Vol. IV, IKB, Academy of Sciences.

Pardini A., P.Talamaci 1990: Combined utilization of Warm and cool season pasture specie in are Mediterranean”.

Rexhepi F. 1988: Grasslands in mountain regions in Kosovo. Prishtina, Kosovo.

Rusinovci I., Fetahu Sh., Zeka D., Bytyqi H., Aliu S. 2016a: Yield and quality traits of some forage crops cultivated under agroecological conditions of Kosova. Agriculture \& Forestry, Vol. 62 Issue 2: 111-118.

Rusinovci I., Aliu S., Fetahu Sh., Zeka D. 2016b: The agronomic performance of some grass mixtures in the Prishtina locality. Journal of Food, Agriculture \& Environment Vol.14 (2): 117-120.

Rusinovci I., Aliu S., Fetahu Sh., Thaqi M., Bardhi N., Lombnaes P 2015: The yield and mineral composition of some pure grass and their mixtures in agroecological conditions in Kosovo. International Symposium on Agriculture, 334-338.

Rusinovci I., Aliu S., Fetahu Sh., Bislimi K., Thaqi M., Bardhi N. 2014a: The mineral composition in grassland growing in Kosova. Albanian Journal Agriculture science, Special edition: 35-38.

Rusinovci I., Aliu S., Bytyqi H., Fetahu Sh., Thaqi M., Bardhi N., Lombnaes P. 2014b: Grassland management for high forage yield and mineral composition in Kosovo. Agriculture and Forestry, Vol. 60. Issue 2: 59-67. 